UDC 378.147.091.31-059.2

DOI: $10.31470 / 2415-3729-2019-9-56-69$

\title{
The Using of Partnership Technology in the Group Educational Activities of Future Primary Classes Teachers
}

\section{Zhanna Vyhrestenko}

Postgraduate student of the Department of Pedagogy

Pereiaslav-Khmelnytskyi Hryhorii Skovoroda State Pedagogical University,

$\triangle$ 30, Sukhomlynskyi Str., Pereiaslav-Khmelnytskyi, Kyiv Region, Ukraine, 08401

E-mail: star1302@meta.ua

ORCID: 0000-0003-4737-693X

Date of receipt of the article: December 05, 2018

Article accepted for publication: February 22, 2019

\section{Використання технології партнерства в груповій навчальній діяльності майбутніх учителів початкових класів}

\section{Жанна Володимирівна Вихрестенко}

аспірант кафедри педагогіки

ДВНЗ «Переяслав-Хмельницький державний педагогічний університет імені Григорія Сковороди»,

$\triangle$ вул. Сухомлинського, 30, м. Переяслав-Хмельницький, Київська обл., Україна, 08401

Дата надходження статті: 05 грудня 2018 р. Стаття прийнята до друку: 22 лютого 2019 р.

\section{Abstract}

The article clarifies that partnership is a collaboration constructing all activities, communication and behavior on the basis of voluntary responsibility and equality in achieving 
common goals and outcomes. It is proved by the author that the technology of cooperation acquired new features in the process of its development, but some of its originally incorporated elements lost their significance. This technology evolved into a technology of partnership, new approaches and methods of achieving results appeared in its structure. The definition of «technology of partnership in education» is specified. It is a system of use in a certain sequence of methods, techniques, strategies and means of subject-subjective interaction of participants in the educational process on the basis of tolerance and creativity. It has been determined that it is important for the partnership technology that it is based on the use of the group work method as the most common form of cooperation. The basic principles of partnership business relationships are the respect for a personality; benevolence, conscious management of the course of interaction, a distributed leadership, a social partnership. The advantages of using partnership technology in students education is to develop their autonomy and reflexivity; to feel freedom in decision making; the opportunity to proceed from own motives, values, ideals, interests and needs in the ways of its activity; for teachers - exemption from continuing care for students, control of each step.

The author believes that the most effective in the formation of partnership relations is the using of methods of intensive learning as a way of cognition, which is carried in the forms of students' common activities, their interaction and information exchange, the common solution of different problems. The intensive teaching of future teachers includes the using of interactive methods, heuristic conversations, and multimedia presentations, discussion of special videos of lessons, using computer-assisted methods, trainings, practical group and individual exercises, modeling of educational processes or situations, group work with author's manuals. The intensive training is carried in the following forms: meetings with wellknown teachers, master classes, competitions in creative works with their discussions.

Key words: higher education, group educational activity, content of education, junior schoolchildren, future teacher, educational process, learning technology, technology of partnership, technology of cooperation. 


\section{References}

1. Basiuk, L., \& Dobroskok, I. (2018). Rozvytok tvorchosti yak neobkhidna umova profesiinoi pidhotovky maibutnikh fakhivtsiv sfery posluh [Development of greativity as a necessary condition for the vocational training of future service sector specialists]. Humanitarium, 39(2), 7-16. Retrieved from http://humanitarium.online/ index.php/ hum/article/view/137 [in Ukrainian].

2. Barabash, O. (2018). Pedagogika partnerstva - suchasnyi typ vzaemodii mizh uchasnykamy osvitnogo protsesu [Partnership pedagogy - the modern type of copperation of participants of the educational process]. Uchitel pochatkovoyi shkoli, 8, 3-7 [in Ukrainian].

3. Bril, G. K. \& Besarabova, T. V. (2013). Pedagogichna tehnologiia spivrobitnytstva ta yii vprovadzhennia $\mathrm{V}$ umovah pochatkovoi silskoi shkoly [Pedagogical technology of cooperation and its implementation in the conditions of primary village school]. Nauka i osvita, 1-2, 134-137 [in Ukrainian].

4. Mitina, A. M. \& Novozhenina, E. V. (2010). Partnerstvo kak printsip optimizatsii obucheniya $\mathrm{V}$ sisteme dopolnitelnogo obrazovaniya vzroslyih [Partnership as a principle of teaching optimizing in the system of additional education for adults]. Almanah sovremennoy nauki $i$ obrazovaniya, 7(38), 138-140 . [in Russian].

5. Bibik, N. M. (Ed.) (2017). Nova ukrainska shkola: poradnyk dlya vchytelia [New Ukrainian School: a teacher's guide]. Kyiv: TOV «Vidavnichiy dim «Pleyadi» [in Ukrainian].

6. Pidlasiy, I. P. (2004). Praktychna pedagogika abo try tehnologiyi [Practical pedagogy or three technologies]. Kyiv:Vidavnichiy Dim «Slovo» [in Ukrainian].

7. Polupan, K. L. (2017). Tehnologiya partnYorstva: osobennosti i slozhnosti pri realizatsii obrazovatelnoy programmyi v universitete [Technology of a partnership: features and difficulties in the implementation of the educational program at the university]. Vyisshee obrazovanie v Rossii, 11 (217), 116-121 [in Russian]. 


\section{Вступ}

Необхідність розв'язання нових соціальнопедагогічних завдань вищої школи визначає потребу в удосконаленні процесу професійно-педагогічної підготовки майбутнього вчителя початкових класів, що базується на використанні сучасних технологій навчання молодших школярів на основі їх спільної праці і партнерства. У системі підготовки майбутніх учителів особливе місце має посідати групова навчальна діяльність, що містить значні можливості для формування особистості молодшого школяра та підвищення його інтересу до навчання. У процесі групової навчальної діяльності студенти вчаться разом, реалізують природне прагнення до спілкування та здатності до співпраці, взаєморозуміння та взаємодопомоги. Використання групової навчальної діяльності залежить від рівня згуртованості іï членів, значущості та корисності для них запропонованих завдань, правильної організації роботи в групі, наявності лідерів тощо. Нові можливості в організації групової навчальної діяльності студентів надає технологія партнерства. За іiі використання створюються умови для розвитку самостійності, наполегливості, умінь керувати власною поведінкою, враховувати думку інших.

На початку XXI століття активізувалися дослідження вчених у напрямку визначення сутності та різновидів педагогічних технологій (А. Алексюк, В. Беспалько, В. Бондар, В. Свдокимов, М. Кларін, Б. Ліхачов, В. Монахов, T. Назарова, А. Нісімчук, О. Падалка, П. Підкасистий, I. Підласий, С. Сисоєва, Г. Селевко, В. Сластьонін, Д. Чернілевський, О. Шпак та ін.).

У наукових колах визначаються різні напрямки i характеристики цієї дефініції. Група науковців (В. Бухвалов, В. Паламарчук, Б. Лихачов, Н. Крилов, М. Мейєр, Р. де Киффер, С. Смирнов та ін.), визначають педагогічні технології як процес застосування організаційнометодичного інструментарію (набір форм, методів, способів, прийомів навчання i виховання), апаратури (ТЗН), навчального обладнання); М. Кларін, В. Давидов, Г. Селевко, П. Мітчел, Д. Фінн, К. Силбер, Р. Томас пропонують 
розглядати педагогічні (освітні) технології як багатогранний процес.

Розглядаючи сучасну теорію та практику проблеми підготовки до групової навчальної діяльності майбутніх учителів початкових класів можна стверджувати, що недостатньо вивчена і розроблена проблема використання технології партнерства в груповій навчальній діяльності майбутніх учителів початкових класів.

Мета статті - теоретично обгрунтувати застосування технології партнерства в підготовці майбутнього вчителя початкових класів. Проаналізувати сучасний стан застосування технології партнерства в підготовці майбутнього вчителя початкових класів.

\section{Матеріал і методи досліджень}

Для досягнення поставленої мети та завдань використовувалися такі методи дослідження: теоретичні (аналіз та узагальнення), емпіричні.

\section{Результати та їх обговорення}

Вища школа сьогодні орієнтована на використання сучасних педагогічних технологій, які перевірені часом i відкривають нові можливості для вдосконалення освітнього процесу. Педагогічна технологія передбачає мистецтво оволодіння педагогічним процесом, у результаті чого вдосконалюються знання, уміння і навички його учасників.

Аналіз різних джерел та сучасної психологопедагогічної літератури доводить існування різних позицій науковців щодо сутності поняття «педагогічна технологія».

В основі сучасної моделі підготовки майбутніх учителів лежить ідея, що учитель у європейському вимірі має бути творчим, націленим на пошук, ініціативним, активним, відкритим для новацій, має бути партнером в діалозі з учнем. Отже, на одне з перших місць у використанні в практиці роботи вищої школи виходять партнерські технології.

Технології співробітництва є різновидом особистісно орієнтованих педагогічних технологій, розглядають технологію співробітництва як напрям у вітчизняній педагогіці другої половини ХX ст., як систему методів i прийомів виховання та навчання на принципах гуманізму й 
творчого підходу до розвитку особистості (Ш. Амонашвілі, І. Волков, І. Іванов, Є. Ільїн, В. Караковський, С. Лисенкова, Л. і Б. Нікітіни, В. Шаталов, М. Щетинін та ін.). Ці вчені виділяють такі основні положення технологій співробітництва:

- ставлення до навчання як до творчої взаємодії вчителя й учня;

- навчання без примусу;

- ідея важкої мети (перед учнем ставиться якомога складніше завдання i вселяється впевненість у іï подоланні);

- ідея великих блоків (об'єднання декількох тем навчального матеріалу, уроків в окремі блоки);

- використання опор (опорні сигнали за системами Шаталова, схеми за Лисенковою, опорні деталі за Ільїним та ін.);

- самоаналіз (індивідуальне й колективне підведення підсумків діяльності учнів);

- вільний вибір (використання вчителем за своїм розсудом навчального часу 3 метою найкращого засвоєння навчального матеріалу);

- інтелектуальний фон класу (постановка значущих життєвих цілей і одержання учнями більш широких порівняно з навчальною програмою знань);

- колективна творча виховна діяльність (колективна методика);

- творче самоврядування учнів;

- особистісний підхід вчителя до виховання;

- співробітництво в колективі вчителів;

- співробітництво вчительського колективу з батьками (Бриль, 2013: 135-136).

Отже, авторські школи і педагогічні системи педагогіки співробітництва набули поширення у вітчизняній педагогіці другої половини XX ст. У описі технологій співробітництва існують багато конкретних ідей удосконалення процесів навчання, виховання і розвитку дітей і молоді. Не всі ці ідеї встояли під натиском суворої критики і нових реалій, не всі вони можуть використовуватися у практиці сучасного 
освітнього процесу. Однак, без усяких змін, до сучасної партнерської технології ввійдуть ідеї: перебудови стосунків 3 учнями (природно, на ринкових засадах); навчання без примусу; застосування опор (опорної наочності, звукової опори, коментованого керування); оцінки учнівських робіт; вільний вибір в усьому розмаїтті палітри застосування; збільшені дидактичні одиниці навчального матеріалу (структуровані знання); розроблені В. Шаталовим листи опорних сигналів та прийоми перевірки знань учнів; особистісний підхід; співробітництво педагогів (Підласий, 2004: 162). К. Полупан стосовно до освітнього процесу в університеті вважає найбільш правильним використання терміна «технологія партнерства» (Полупан, 2017: 116). Підтримуємо цю думку автора, що ця назва $є$ найбільш оптимальною, бо достатньо чітко дає уяву про іï сутність.

У процесі розвитку технологія співробітництва (співпраці) набула нових особливостей, деякі, первісно закладені в ній елементи, втратили свою вагу. Натомість, зазначена технологія еволюціонувала в технологію партнерства, у іï структурі з'являлися нові підходи, методи досягнення результату.

У сучасних педагогічних дослідженнях немає єдності поглядів на феномен партнерства. Як зауважують А. Мітіна i $€$. Новоженіна, воно трактується по-різному: як форма реалізації співробітництва (Г. Селевко), умова оптимального спілкування у педагогічній діяльності (Ю. Кулюткин), вища форма педагогічних взаємодій при вирішенні творчих завдань (В. Ляудіс), принцип педагогічної взаємодії (Д. Белухин), підструктура особистісно розвиваючої ситуації (С. Крюкова). Деякі дослідники проблем освіти використовують поняття «співпраця» $\mathrm{i}$ «партнерство» як синонімічні, взаємозамінні. На погляд цих науковців, їх не можна вважати повністю ідентичними. Еталонним критерієм співробітництва виступає певний рівень внутрішньої самоорганізації особистості. Так як здатність до партнерства $\epsilon$ показником вищої форми самоорганізації, то А. Мітіна і С. Новоженіна роблять висновок, що співпраця породжує партнерство. Таким чином, партнерство - це 
співробітництво, що конструює всю спільну діяльність, спілкування і поведінку на основі добровільної відповідальності та рівності в досягненні загальних цілей і результатів діяльності (Мітіна, 2010: 138). О. Барабаш педагогіку партнерства розглядає як напрям педагогіки, який передбачає узагальнення, проектування оптимальних умов, прийомів, методів формування та розвитку особистості школяра на гуманістичних засадах (Барабаш, 2017: 3).

Особливостями партнерства вважається позитивне та гуманістичне ставлення до іншої людини як до рівної, з якою потрібно співпрацювати на основі спільної мети 3 урахуванням власних прагнень, узгодженні своїх інтересів i намірів 3 груповими. Взаємна активність учасників освітнього процесу при застосуванні технології партнерства позначається такими сучасними термінами як «педагогічне співробітництво», «педагогічне партнерство», «педагогічна взаємодія». У цьому ракурсі взаємодія виступає як своєрідне втілення певних зв'язків, взаємин між учасниками освітнього процесу, які вирішують спільні завдання і досягають успіху в їх розв'язанні.

Психологічну основу педагогіки співробітництва

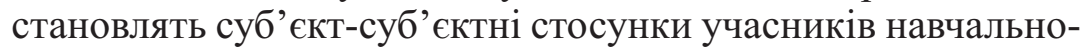
виховного процесу, їх співпраця побудована на толерантній взаємодії в освітньому середовищі, що функціонує на засадах творчості. Толерантність передбачає визнання різноманіття поглядів, життєвих принципів, цінностей інших людей; терпимість до оточуючих i навколишніх подій. Рівноправність учасників освітнього процесу на суб'єктсуб'єктній основі в процесі впровадження технології партнерства стосуються узгодженості їх позицій і певних дій.

Основними принципами педагогіки партнерства $є$ : повага до особистості; доброзичливість i позитивне ставлення; довіра у відносинах, стосунках; діалог взаємодія - взаємоповага; розподілене лідерство (проактивність, право вибору та відповідальність за нього, горизонтальність зв'язків); принципи соціального партнерства (рівність сторін, добровільність прийняття зобов'язань, обов'язковість виконання домовленостей). 
Педагогіка співробітництва і педагогіка партнерства базуються на спільних принципах, однак педагогіка партнерства передбачає більш широке поле актуалізації соціально-педагогічного процесу - соціальне партнерство. Сучасна школа не може існувати ізольовано від оточуючих іiі соціальних інститутів. Найважливішим завданням сучасної освіти є успішна соціалізація дітей та молоді, яка неможлива без чіткого їх уявлення про навколишнє соціальне середовище. Соціальне партнерство розуміється як специфічний тип суспільних відносин між різними соціальними групами, прошарками й класами, які мають суттєво відмінні інтереси, на засадах рівноправ'я сторін у свободі вибору, взаємопідтримки, взаємовідповідальності.

Таким чином, використання педагогіки партнерства (співробітництва) набуває сьогодні нових особливостей i акцентів. Педагогіка співробітництва набуває популярності в сучасній європейській освіті, яка своєю головною метою вважає надання особистості потужної життєвої мотивації, формування іiі потенціалу як системи творчих здібностей i передумов їх реалізації, виховання їі впевненою у своїх правах і свідомою в обов'язках, надання їй автономності як запоруки їі самоактуалізації.

Сьогодні у практиці використання технології партнерства існують різні їі модифікації. $€$ очевидним, що наявність вміння співпрацювати стає обов'язковою складовою більшості сучасних педагогічних технологій, які передбачають обговорення проблеми в груповому режимі (проектні, ігрові, інтерактивні, діалогові технології тощо). Найбільш ефективним у формуванні відносин партнерства вважається застосування методів інтенсивного навчання як способу пізнання, який здійснюваний в формах спільної діяльності студентів, їх взаємодії та обміну інформацією, спільного розв'язання різних проблеми. До інтенсивного навчання майбутніх учителів відноситься використання інтерактивних методів, евристичної бесіди, мультимедійних презентацій, обговорення спеціальних відеозаписів уроків, методи $з$ використанням комп'ютерної техніки, тренінги, практичні групові та індивідуальні вправи, моделювання 
освітніх процесів або ситуацій, групова робота з авторськими посібниками. Інтенсивне навчання здійснюється у таких формах: зустрічі із відомими вчителями, майстер-класи, конкурси творчих робіт з їх обговоренням тощо.

Різновидами технології партнерства $\epsilon$ перехід на навчання за контрактами, взаємонавчання, коопероване навчання, колективний пошук знань, проблемне навчання, проектне навчання, інтенсивне навчання тощо.

При використанні технології партнерства в освітньому процесі важливо усвідомити їі позитивні сторони та труднощі в іii реалізації. Так, до позитивних наслідків впровадження технології партнерства в освітні програми, що реалізуються в університеті, відносимо наступні:

- пріоритет цілей розвитку індивідуальності, реалізація кожної окремої особистості в партнерській взаємодії;

- $\quad$ формування цінностей, ідеалів, зразків у партнерстві 3 урахуванням особистих інтересів і потреб;

- комплексне багатоаспектне вирішення професійних завдань, проблем, ситуацій;

- можливість вільного вибору, що відповідає інтересам і бажанням кожного партнера;

- створення умов для самовизначення учасників діяльності (рефлексія своєї ролі, характеру поведінки і форм взаємодії);

- оцінювання результатів спільної діяльності з точки зору розвитку особистості кожного учасника в контексті його відносин з партнерами.

Отже, плюсами партнерства в навчанні для студентів $€$ розвиток їх самостійності та рефлексивності; свобода в прийнятті рішень; можливість виходити з власних мотивів, цінностей, ідеалів, інтересів і потреб у способах своєї діяльності; зменшення поля невизначеності у діяльності, стресових ситуацій.

Позитивні наслідки при використанні технологій партнерства отримують i викладачі. Так, партнерство звільняє викладача від догляду за студентом, контролювання кожного його кроку, «замаху» на його вибір і сферу відповідальності. Викладач почуває себе набагато 
комфортніше і отримує більшого визнання як професіонал. Таким чином, необхідність застосування технології партнерства у вищій школі продиктована необхідністю взаємодії учасників освітнього процесу для подолання наслідків індивідуального характеру навчальної діяльності суб'єктів і розвитку їх прагнень узгоджувати власні інтереси 3 бажаннями інших людей, вміти працювати в команді. Основна мета такої педагогічної технології - сформувати в учасників взаємодії навички спільної роботи в малій групі, домагаючись при цьому якісних освітніх результатів.

Отже, педагогіка партнерства вимагає переосмислення ролі викладача в iї організації, що полягає в оновленні його професійного мислення й розвитку відповідних професійних компетентностей: створення інтелектуального поля діяльності з чітко визначеними результатами і видами діяльності; орієнтація на дослідницький характер освітнього процесу; постійний аналіз власної педагогічної діяльності; вдосконалення комунікативних вмінь та навичок; орієнтація на самоосвіту та самовдосконалення; підвищення результативності своєї роботи через систему моніторингу тощо.

\section{Висновки}

У процесі грунтовного аналізу психолого-педагогічної літератури 3'ясовано, що в процесі розвитку технологія співробітництва (співпраці) набула нових особливостей, деякі, первісно закладені в ній елементи, втратили свою вагу. Натомість, зазначена технологія еволюціонувала в технологію партнерства, у іï структурі з'являлися нові підходи, методи досягнення результату. Уточнено визначення поняття «технологія партнерства в освіті» - це система використання у певній послідовності методів, прийомів, стратегій та засобів суб'єкт-суб'єктної взаємодії учасників освітнього процесу на засадах толерантності та творчості. Визначено, що важливим для технології партнерства $є$ те, що вона будується на використанні методу групової роботи як найбільш поширеної форми кооперації. Основними принципами партнерських ділових взаємин є повага до особистості; доброзичливість, свідоме управління ходом 
взаємодії, розподілене лідерство, соціальне партнерство. Плюсами застосування технології партнерства в навчанні студентів є розвиток їх самостійності та рефлексивності; свобода в прийнятті рішень; можливість виходити з власних мотивів, цінностей, ідеалів, інтересів і потреб у способах своєї діяльності; для викладачів - звільнення від постійного догляду за студентами, контролювання кожного їх кроку.

Перспективою подальших розвідок може бути теоретичний аналіз форм та методів формування готовності майбутніх учителів початкових класів до групової навчальної діяльності засобами технології партнерства.

\section{Література}

1. Басюк Л.В., Доброскок І.І. Розвиток креативності як необхідна умова професійної підготовки майбутніх фахівців сфери обслуговування. Humanitarium. 2017. Том. 39, Вип. 2 : Педагогіка. С. 7-16.

2. Барабаш О. Педагогіка партнерства - сучасний тип взаємодії між учасниками освітнього процесу. Учитель початкової школи. 2018. №8. С.3-7.

3. Бриль Г. К., Бесарабова Т. В. Педагогічна технологія співробітництва та її впровадження в умовах початкової сільської школи. Наука і освіта. 2013. №1-2. С. 134-137.

4. Митина А. М., Новоженина Е. В. Партнерство как принцип оптимизации обучения в системе дополнительного образования взрослых. Альманах современной науки и образования. 2010. № 7(38). C. 138-140.

5. Нова українська школа: порадник для вчителя / Під заг. ред. Н. М. Бібік. Київ: ТОВ «Видавничий дім «Плеяди», 2017. 206 c.

6. Підласий І. П. Практична педагогіка або три технології. Інтерактивний підручник для педагогів ринкової системи освіти. Київ:Видавничий Дім «Слово», 2004. $616 \mathrm{c}$.

7. Полупан К. Л. Технология партнёрства: особенности и сложности при реализации образовательной программы в университете. Высшее образование в России. 2017. № 11 (217). С. 116-121. 


\section{Вихрестенко Ж.В.}

\section{Використання технології партнерства в груповій} навчальній діяльності майбутніх учителів початкових класів

\section{Анотація}

У статті 3'ясовано, що партнерство - це співробітництво, що конструює всю спільну діяльність, спілкування i поведінку на основі добровільної відповідальності та рівності в досягненні загальних цілей і результатів діяльності. Доведено, що в процесі розвитку технологія співробітництва набула нових особливостей, деякі, первісно закладені в ній елементи, втратили свою вагу. Натомість, зазначена технологія еволюціонувала в технологію партнерства, у iï структурі 3'являлися нові підходи, методи досягнення результату. Визначено, що важливим для технології партнерства є те, що вона будується на використанні методу групової роботи як найбільш поширеної форми кооперації. Основними принципами партнерських ділових взаємин є повага до особистості; доброзичливість, свідоме управління ходом взаємодії, розподілене лідерство, соціальне партнерство.

Ключові слова: вища освіта, групова навчальна діяльність, зміст освіти, молодші школярі, майбутній учитель, освітній процес, технологія навчання, технологія партнерства, технологія співробітництва.

\section{Выхрестенко Ж.В.}

Использование технологии партнерства в групповой учебной деяльности будущих учителей начальных классов

\section{Аннотация}

В статье установлено, что в процессе развития технологии сотрудничества приобрела новые особенности, некоторые, первоначально заложенные в ней элементы, 
потеряли свое значение. Указанная технология эволюционировала в технологию партнерства, в ее структуре появлялись новые подходы, методы достижения результата. Определено, что важным для технологии партнерства является то, что она строится на использовании метода групповой работы как наиболее распространенной формы кооперации. Основными принципами партнерских деловых отношений является уважение к личности; доброжелательность, сознательное управление ходом взаимодействия, распределенное лидерство, социальное партнерство.

Ключевые слова: высшее образование, групповая учебная деятельность, содержание образования, младшие школьники, будущий учитель,, образовательный процесс, технология обучения, технология партнерства, технология сотрудничества. 